\title{
New linkage data for the X-linked types of muscular dystrophy and G6PD variants, colour blindness, and $\mathrm{Xg}$ blood groups
}

\author{
MAYANA ZATZ,* SUELI B. ITSKAN,† RUTH SANGER, $¥$ O. FROTA-PESSOA,* and \\ P. H. SALDANHA†
}

\begin{abstract}
Summary. Six families in which Duchenne muscular dystrophy (DMD) and G6PD or deutan colour blindness are segregating are reported. The sum of the lod-scores of these families together with three published previously indicates that the DMD locus is far from the G6PD: deutan cluster. The lod-scores of two families with Becker muscular dystrophy (BMD) informative for the G6PD locus together with those of one family previously studied by Emery, Smith, and Sanger (1969) suggest that the BMD locus could be at a measurable distance from this cluster. The maximum likelihood estimate of the recombination fraction is $0 \cdot 27$ and the $90 \%$ confidence limits are 0.17 and 0.40 . This difference in linkage estimates for DMD and BMD suggests that the BMD and the DMD genes are located at two different loci on the $\mathrm{X}$ chromosome.

Five more families with DMD and two with BMD informative for $\mathrm{Xg}$ blood groups support the conclusion of other authors that there is no hint of linkage between the loci for $\mathrm{Xg}$ and for the $\mathrm{X}$-linked forms of muscular dystrophy.
\end{abstract}

Philip, Walton, and Smith (1956) were the first to report a family where Duchenne muscular dystrophy (DMD) and colour blindness genes were segregating. They found five recombinants among 20 individuals. The linkage analysis, by the lodscore method, of three other families (Emery, 1966) informative for Duchenne type of dystrophy and deutan colour blindness suggests that these two genes are quite far apart on the $\mathrm{X}$ chromosome.

Emery et al (1969) restudied and extended the genealogy of the family originally described by Philip et al (1956) and concluded that the affected members had the Becker type of muscular dystrophy (BMD). The results of linkage analysis of the pedigree suggested that the loci for BMD and deutan colour blindness may be not far from each other. The authors remarked that indirect evidence on the Becker: deutan interval might be pro-

\footnotetext{
Received 6 June 1974.

* Laboratório de Genética Humana, Instituto de Biociências, Universidade de São Paulo, São Paulo, Brazil.

† Laboratório de Genética Médica, Faculdade de Medicina, Universidade de São Paulo, São Paulo, Brazil.

¥ MRC Blood Group Unit, Lister Institute, London, United Kingdom.
}

vided by families in which $B M D$ and G6PD variants are segregating, since it is established that the loci for deutan colour blindness and G6PD are closely linked (Adam, 1961; Porter, Schulze, and McKusick, 1962; Siniscalco, 1963; Fraser et al, 1964). Apparently, however, no report has yet been made on such families.

In this communication the results of linkage studies of two Brazilian families where BMD and G6PD genes are segregating are reported. Further, six families with boys affected by DMD which are informative for G6PD or deutan colour blindness are recorded: three of these families are also informative for the $\mathrm{Xg}$ locus. In four other families the $\mathrm{Xg}$ blood groups were informative for linkage analysis, two with DMD and two with BMD.

\section{Subjects}

Families were studied only when there were two or more affected males or when two or more females related to an isolated case had substantially elevated creatine-phosphokinase (CPK) levels. In each family the diagnosis of muscular dystrophy was established through clinical examination, muscle biopsy, electro- 


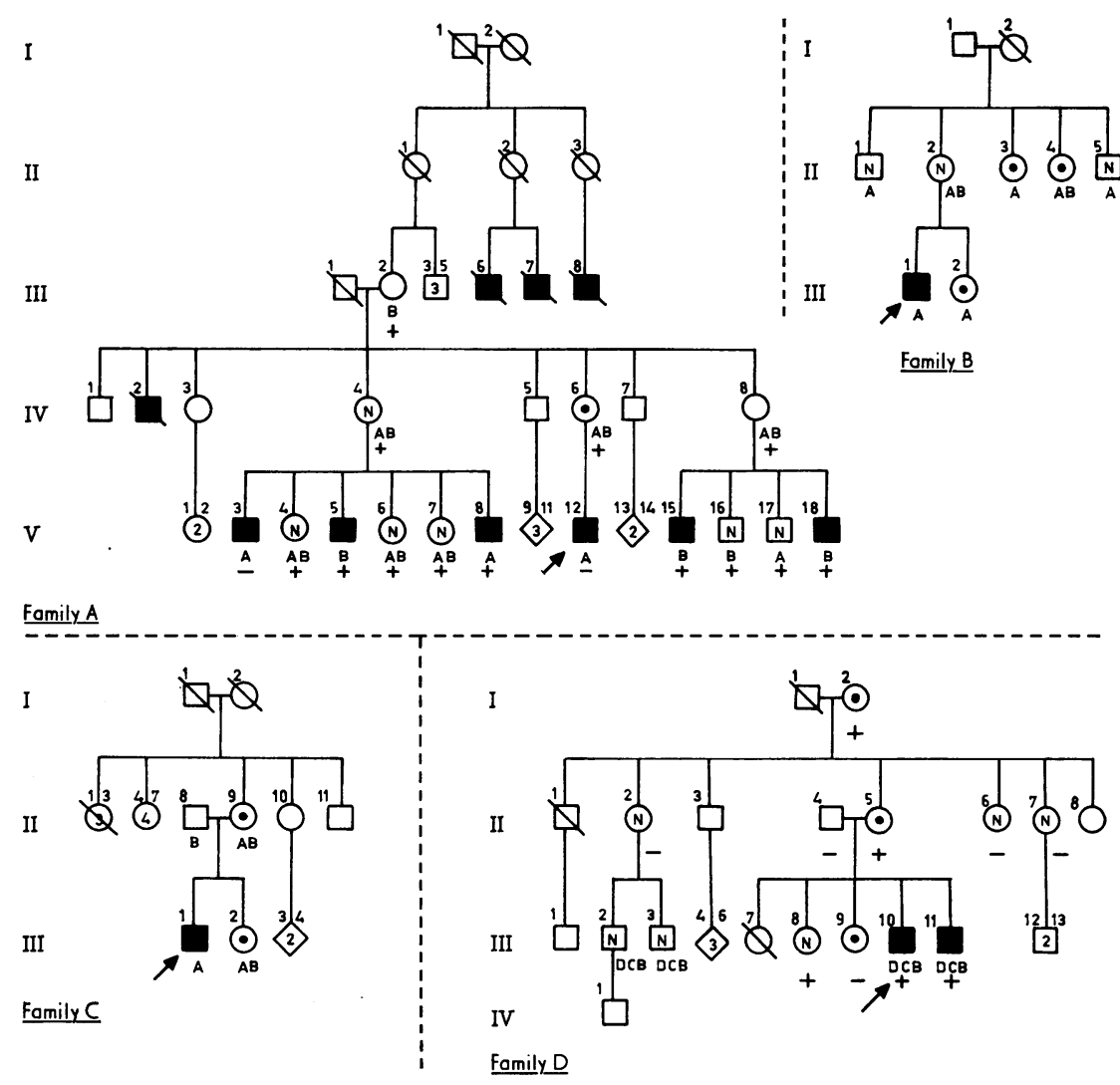

Fig. 1a. Pedigrees of families A, B, C, and D.

myography, and CPK activity. For the analysis of recombinants only females with raised CPK levels were scored as carriers of the muscular dystrophy gene. Women with low CPK activity were not considered as non-carriers since in our laboratory $39 \%$ of the certain carriers of the DMD gene and three among eight of those carrying the BMD gene were found to have normal CPK activity. Females with normal G6PD activity were considered as heterozygotes only when they had a deficient father or son.

\section{Methods}

The serum CPK activity was determined in fresh samples of blood by the method described in the Sigma Bulletin (1967). The upper limit of normality was considered to be 20.0 Sigma units for males and 12.0 Sigma units for females.

The study of G6PD was made by spectrophotometric assay and G6PD variants were identified by horizontal starch gels. These methods are described in detail in Saldanha, Nobrega, and Maia (1969).

Ishihara plates and the AO-HRR (American Optical
Hardy-Rand-Rittler) pseudoisochromatic plates were used for colour vision tests.

The determination of $\mathrm{Xg}$ groups was performed at the MRC Blood Group Unit, London.

\section{Linkage analysis}

The data were analysed by the application of the lod-scores of Morton (1955) as set out in the tables of Maynard-Smith, Penrose, and Smith (1961). The lod-scores are given in Tables I to IV, together with the antilogs of their sums, which represent the relative probabilities of the recombination fraction $\theta$.

DMD and G6PD or deutan colour blindness. In families A, B, and C (Fig. 1), DMD and G6PD-A variant genes are segregating. Family $\mathbf{A}$ is also informative for $\mathrm{Xg}$ groups.

Families D, E, and F (Fig. 1) are informative for Duchenne dystrophy and deutan colour blindness. Families $\mathrm{D}$ and $\mathrm{E}$ are also informative for $\mathrm{Xg}$ groups. 




Fomily E

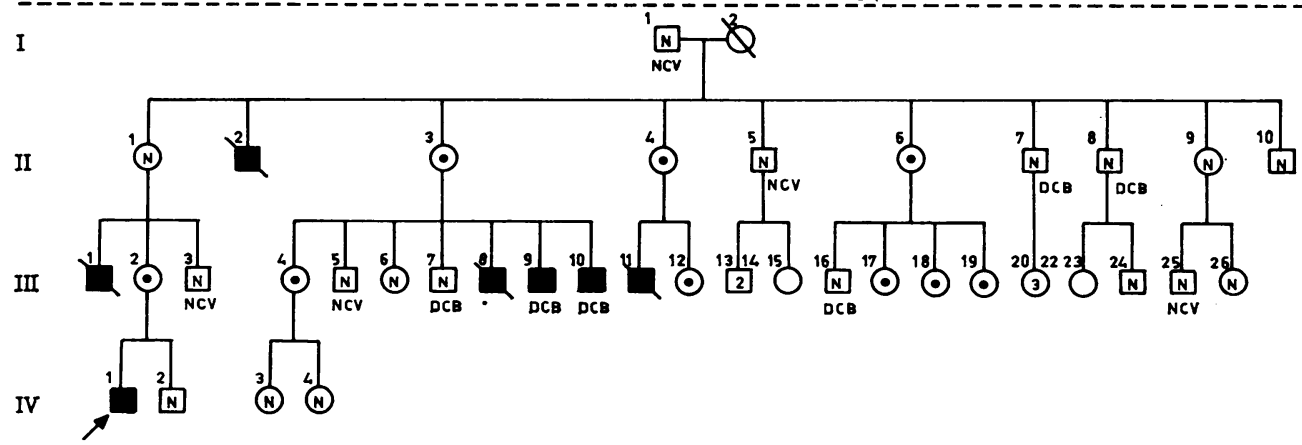

Family $F$

Duchenne muscular dystrophy

$\square \bigcirc_{N}$ Normal G6PD activity
$\square$ Normal colour vision

2 Becker muscular dystrophy $+x_{g}(0+)-x_{g}(0-) \odot$ Roised CPK level (N) Normal CPK level

$\square_{D} \bigcirc_{D}$ G6PD deficiency $\square_{\boldsymbol{A}} \bigcirc_{\boldsymbol{A}} \square_{B} \bigcirc_{\mathbf{A}} \bigcirc_{A B}$ G6PD electrophoretic pottern

$\square_{\mathrm{OCB}}$ Deutan colour blindness

FIG. 1b.-Pedigrees of families E and F.

The sum of lod scores of these six families together with three studied by Emery (1966) are shown in Table I. The antilogs of these are plotted in Fig. 2 (curve D).

BMD and G6PD. Families $\mathrm{G}$ and $\mathrm{H}$ (Fig. 3) are informative for BMD and G6PD loci. Table II gives the scores of these two families and of one published previously by Emery et al (1969) where the BMD gene and the deutan colour blindness gene are segregating; the antilogs of the lod-score sums are plotted in Fig. 2 (curve B). The most likely estimate of $\theta$ is 0.27 and the $90 \%$ confidence limits are 0.17 and $0 \cdot 40$. These limits were obtained following the suggestion of Dr C. A. B. Smith (Opitz et al, 1965) of counting the graph paper squares below the curve and cutting off from each tail $1 / 20$ of their number.

DMD and Xg. Two families (I and J, Fig. 4) with DMD are informative for $\mathrm{Xg}$ groups. The sum of scores of these two families and of three represented in Fig. 1 (A, D, and E) are shown in Table III together with 20 others previously published (Clark et al, 1963; Blyth et al, 1965; Filippi and Macciotta, 1967).

BMD and Xg. Table IV gives the scores of two new families (K and L, Fig. 5) together with five 
TABLE I

LOD-SCORES FOR DUCHENNE-TYPE MUSCULAR DYSTROPHY, G6PD, AND DEUTAN COLOUR BLINDNESS

\begin{tabular}{|c|c|c|c|c|c|c|c|c|c|}
\hline & \multicolumn{9}{|c|}{ Recombination Fraction $(\theta)$} \\
\hline & 0.05 & $0 \cdot 1$ & $0 \cdot 15$ & 0.2 & $0 \cdot 25$ & $0 \cdot 3$ & 0.35 & $0 \cdot 4$ & 0.45 \\
\hline $\begin{array}{l}\text { Present study } \\
\text { DMD and G6PD } \\
\begin{array}{ll}\text { Family A } & 4 \mathrm{n}-\mathrm{r}: 4 \mathrm{r} \\
\text { Family } \mathrm{B} & \mathrm{z}_{1} 4: 1 \mathrm{e}_{1} \quad 3: 2 \\
& \text { On }-\mathrm{r}: 2 \mathrm{r} \\
\text { Family C } & \mathrm{z}_{1} 2: 0\end{array} \\
\end{array}$ & $\begin{array}{r}-2.884 \\
-0.199 \\
-2.000 \\
0.258\end{array}$ & $\begin{array}{r}-1.776 \\
0.010 \\
-1.398 \\
0.215\end{array}$ & $\begin{array}{r}-1.772 \\
0.089 \\
-1.046 \\
0.173 \\
\end{array}$ & $\begin{array}{r}-0.776 \\
0.116 \\
-0.796 \\
0.134\end{array}$ & $\begin{array}{r}-0.600 \\
0.112 \\
-0.602 \\
0.097\end{array}$ & $\begin{array}{r}-0.304 \\
0.091 \\
-0.444 \\
0.064\end{array}$ & $\begin{array}{r}-0.164 \\
0.061 \\
-0.310 \\
0.037\end{array}$ & $\begin{array}{r}-0.072 \\
0.030 \\
-0.194 \\
0.017\end{array}$ & $\begin{array}{r}-0.020 \\
0.008 \\
-0.092 \\
0.004\end{array}$ \\
\hline Sum of lod-scores & $-4 \cdot 825$ & -2.949 & $-2 \cdot 556$ & $-1 \cdot 322$ & -0.993 & -0.593 & -0.376 & $-0 \cdot 219$ & $-0 \cdot 100$ \\
\hline 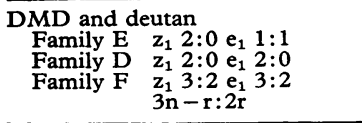 & $\begin{array}{r}0.154 \\
0.395 \\
-1.455 \\
-1.163\end{array}$ & $\begin{array}{r}0.131 \\
0.319 \\
-0.899 \\
-0.633\end{array}$ & $\begin{array}{r}0.107 \\
0.250 \\
-0.595 \\
-0.356\end{array}$ & $\begin{array}{r}0.085 \\
0.190 \\
-0.396 \\
-0.184\end{array}$ & $\begin{array}{r}0.062 \\
0.135 \\
-0.256 \\
-0.074\end{array}$ & $\begin{array}{r}0.041 \\
0.088 \\
-0.155 \\
-0.006 \\
\end{array}$ & $\begin{array}{r}0.024 \\
0.050 \\
-0.084 \\
0.032\end{array}$ & $\begin{array}{r}0.011 \\
0.023 \\
-0.036 \\
0.043\end{array}$ & $\begin{array}{r}0.003 \\
0.005 \\
-0.009 \\
0.031\end{array}$ \\
\hline Sum of lod-scores & $-2 \cdot 069$ & $-1 \cdot 082$ & -0.594 & $-0 \cdot 305$ & -0.133 & -0.032 & 0.022 & 0.041 & 0.030 \\
\hline $\begin{array}{l}\text { Other studies } \\
\text { DMD and deutan (Emery, 1966) } \\
3 \text { families }\end{array}$ & $-1 \cdot 747$ & -0.973 & -0.571 & -0.322 & $-0 \cdot 161$ & -0.058 & 0.004 & 0.031 & 0.028 \\
\hline Total sum of lod-scores & $-8 \cdot 641$ & $-5 \cdot 004$ & $-3 \cdot 721$ & -1.949 & $-1 \cdot 287$ & -0.683 & -0.350 & $-0 \cdot 147$ & -0.042 \\
\hline Antilog = relative likelihood & 0 & 0 & 0 & 0.01 & 0.05 & $0 \cdot 2$ & $0 \cdot 4$ & 0.7 & 0.9 \\
\hline
\end{tabular}

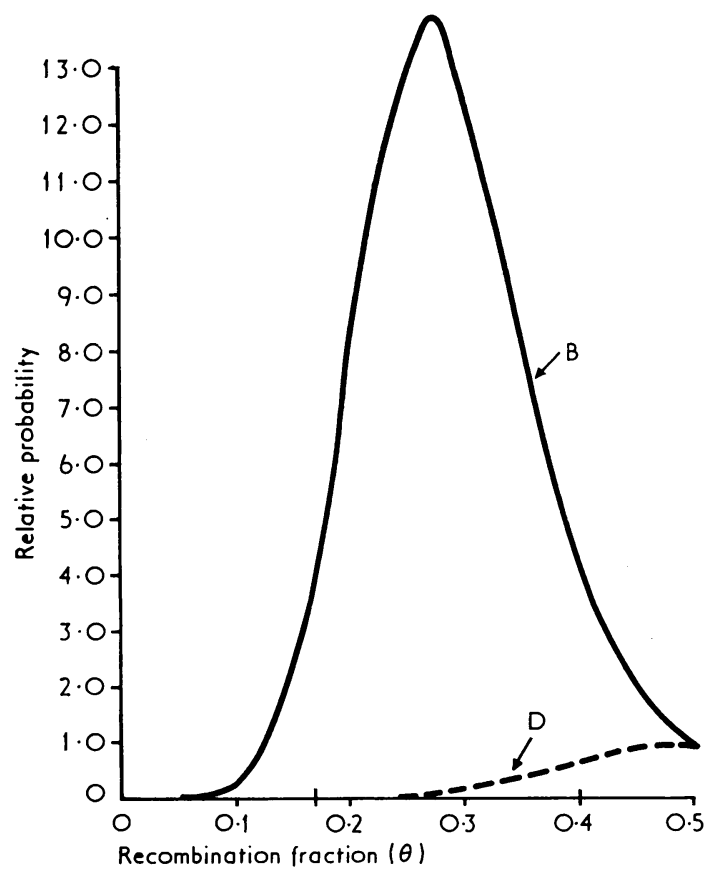

Frg. 2. Relative probabilities of various recombination fractions for deutan colour blindness plus G6PD with Duchenne-type muscular dystrophy (curve D) and Becker type muscular dystrophy (curve B). others published previously by Blyth et al (1965) and Emery et al (1969).

\section{Discussion}

Becker (1955) and Becker and Kiener (1955) suggested that the two forms of X-linked muscular dystrophy might be produced by different mutations, possibly allelic. Rotthauwe and Kowalewski (1966) tend to accept that the severe and the benign forms of sex-linked muscular dystrophy are caused by allelomorphic mutants of the same gene. Walton (1969) suggests the possibility that in the benign variety a modifier gene is so closely linked to the single muscular dystrophy locus that no pedigree including both severe and benign cases has been recorded.

If, however, by linkage studies it could be demonstrated that the Duchenne and the Becker loci are sited at different distances from a marker locus on the $\mathrm{X}$ chromosome, the two forms of muscular dystrophy would have to be assigned to distinct loci.

$\mathrm{Xg}$ blood groups were determined in several families with Duchenne and Becker muscular dystrophy (Clark et al, 1963; Blyth et al, 1965; Filippi and Macciotta, 1967; Emery et al, 1969) and no evidence of linkage between $\mathrm{Xg}$ and Duchenne or Becker loci was found. The sum of the lod-scores 




Fig. 3. Pedigrees of families G and H.

TABLE II

LOD-SCORES FOR BECKER-TYPE MUSCULAR DYSTROPHY (BMD), G6PD, AND DEUTAN COLOUR BLINDNESS

\begin{tabular}{|c|c|c|c|c|c|c|c|c|c|}
\hline & \multicolumn{9}{|c|}{ Recombination Fraction $(\theta)$} \\
\hline & 0.05 & $0 \cdot 1$ & $0 \cdot 15$ & $0 \cdot 2$ & $0 \cdot 25$ & $0 \cdot 3$ & 0.35 & 0.4 & 0.45 \\
\hline 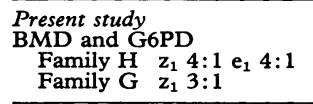 & $\begin{array}{l}-0 \cdot 191 \\
-0.464 \\
\end{array}$ & $\begin{array}{r}0.023 \\
-0.229 \\
\end{array}$ & $\begin{array}{r}0 \cdot 103 \\
-0 \cdot 119 \\
\end{array}$ & $\begin{array}{r}0.129 \\
-0.060 \\
\end{array}$ & $\begin{array}{r}0.122 \\
-0.028 \\
\end{array}$ & $\begin{array}{r}0.098 \\
-0.011\end{array}$ & $\begin{array}{r}0.065 \\
-0.003 \\
\end{array}$ & $\begin{array}{r}0.032 \\
-0.001 \\
\end{array}$ & $\begin{array}{r}0.008 \\
-0.000 \\
\end{array}$ \\
\hline Sum of lod-scores & -0.655 & $-0 \cdot 206$ & -0.016 & 0.069 & 0.094 & 0.087 & 0.062 & 0.031 & 0.008 \\
\hline $\begin{array}{l}\text { Other studies } \\
\text { Emery et al (1969) } 1 \text { family }\end{array}$ & $-2 \cdot 386$ & -0.483 & 0.394 & 0.831 & 1.009 & 1.006 & 0.863 & 0.609 & $0 \cdot 288$ \\
\hline Total sum of lod-scores & -3.041 & -0.689 & 0.378 & 0.900 & $1 \cdot 103$ & 1.093 & 0.925 & 0.640 & $0 \cdot 296$ \\
\hline Antilog $=$ relative likelihood & 0 & $0 \cdot 2$ & $2 \cdot 39$ & $7 \cdot 94$ & $12 \cdot 68$ & $12 \cdot 39$ & $8 \cdot 41$ & $4 \cdot 37$ & 1.98 \\
\hline
\end{tabular}

of seven more families informative for $\mathrm{Xg}$ reported in the present study (five with DMD and two with BMD patients) do not change this situation. The $\mathrm{Xg}$ locus is not, therefore, a useful marker in this connection.

The analysis of our six families with Duchenne dystrophy in addition to the three studied

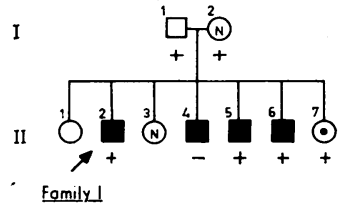



Fomily

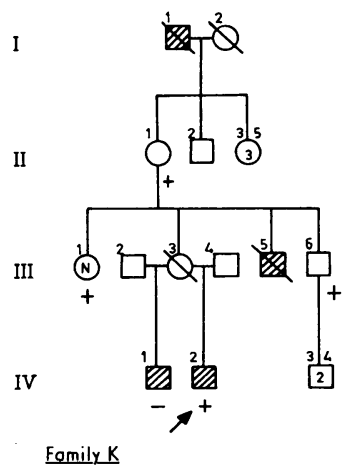

FIG. 5. Pedigrees of families $\mathrm{K}$ and $\mathrm{L}$. 
TABLE III

LOD-SCORES FOR DUCHENNE-TYPE MUSCULAR DYSTROPHY (DMD) AND Xg

\begin{tabular}{|c|c|c|c|c|c|c|c|c|c|}
\hline & \multicolumn{9}{|c|}{ Recombination Fraction $(\theta)$} \\
\hline & 0.05 & $0 \cdot 1$ & $0 \cdot 15$ & $0 \cdot 2$ & $0 \cdot 25$ & 0.3 & 0.35 & 0.4 & 0.45 \\
\hline $\begin{array}{ll}\text { Present study } & \\
\text { Family A } & \mathrm{z}_{1} 2: 1 \mathrm{e}_{1} 3: 0 \\
\text { Family E } & \mathrm{z}_{1} 2: 2 \\
& 2 \mathrm{n}-\mathrm{r}: 0 \mathrm{r} \\
\text { Family D } & 2 \mathrm{n}-\mathrm{r}: 1 \mathrm{r} \\
\text { Family J } & \mathrm{z}_{1} 4: 3 \mathrm{e}_{1} 5: 2 \\
\text { Family I } & \mathrm{z}_{1} 3: 1 \mathrm{e}_{1} 4: 0\end{array}$ & $\begin{array}{r}-0.536 \\
-1.442 \\
0.558 \\
-0.442 \\
-2.167 \\
-0.266\end{array}$ & $\begin{array}{r}-0.305 \\
-0.887 \\
0.510 \\
-0.189 \\
-1.333 \\
-0.084\end{array}$ & $\begin{array}{r}-0.190 \\
-0.585 \\
0.460 \\
-0.063 \\
-0.878 \\
-0.016\end{array}$ & $\begin{array}{r}-0.121 \\
-0.388 \\
0.408 \\
0.010 \\
-0.583 \\
0.012\end{array}$ & $\begin{array}{r}-0.076 \\
-0.250 \\
0.352 \\
0.051 \\
-0.375 \\
0.020\end{array}$ & $\begin{array}{r}-0.045 \\
-0.151 \\
0.292 \\
0.070 \\
-0.227 \\
0.019\end{array}$ & $\begin{array}{r}-0.024 \\
-0.082 \\
0.228 \\
0.073 \\
-0.123 \\
0.013\end{array}$ & $\begin{array}{r}-0.010 \\
-0.035 \\
0.158 \\
0.061 \\
-0.053 \\
0.006\end{array}$ & $\begin{array}{r}-0.002 \\
-0.089 \\
0.082 \\
0.036 \\
-0.013 \\
0.002\end{array}$ \\
\hline Sum of lod-scores & $-4 \cdot 295$ & $-2 \cdot 288$ & $-1 \cdot 272$ & -0.662 & -0.278 & -0.042 & 0.085 & $0 \cdot 127$ & 0.016 \\
\hline $\begin{array}{l}\text { Other studies } \\
\text { Clark et al (1963) } 7 \text { families } \\
\text { Blyth et al (1965) } 10 \text { families } \\
\text { Filippi and Macciotta (1967) } 3 \text { families }\end{array}$ & $\begin{array}{r}-6.036 \\
-11.682 \\
-2 \cdot 163\end{array}$ & $\begin{array}{l}-3.577 \\
-7.461 \\
-1.332\end{array}$ & $\begin{array}{l}-\overline{5 \cdot 114} \\
-0.876\end{array}$ & $\begin{array}{l}-1.475 \\
-3.552 \\
-0.582\end{array}$ & $\begin{array}{l}-0.935 \\
-2.427 \\
-0.375\end{array}$ & $\begin{array}{l}-0.566 \\
-1.596 \\
-2.228\end{array}$ & $\begin{array}{l}-0.313 \\
-0.969 \\
-0.123\end{array}$ & $\begin{array}{l}-0.147 \\
-0.511 \\
-0.054\end{array}$ & $\begin{array}{l}-0.046 \\
-0.193 \\
-0.012 \\
\end{array}$ \\
\hline Sum of lod-scores & $-19 \cdot 881$ & $-12 \cdot 370$ & - & $-5 \cdot 609$ & $-3 \cdot 737$ & $-2 \cdot 390$ & $-1 \cdot 405$ & -0.712 & -0.251 \\
\hline Total sum of lod-scores & $-24 \cdot 176$ & $-14 \cdot 658$ & - & $-6 \cdot 271$ & $-4 \cdot 015$ & $-2 \cdot 432$ & $-1 \cdot 320$ & -0.585 & -0.235 \\
\hline Antilog $=$ relative likelihood & 0 & 0 & 0 & 0 & 0 & 0 & 0.05 & $0 \cdot 26$ & 0.58 \\
\hline
\end{tabular}

TABLE IV

LOD-SCORES FOR BECKER-TYPE MUSCULAR DYSTROPHY (BMD) AND Xg

\begin{tabular}{|c|c|c|c|c|c|c|c|c|c|}
\hline & \multicolumn{9}{|c|}{ Recombination Fraction $(\theta)$} \\
\hline & 0.05 & $0 \cdot 1$ & $0 \cdot 15$ & $0 \cdot 2$ & $0 \cdot 25$ & $0 \cdot 3$ & 0.35 & 0.4 & 0.45 \\
\hline  & $\begin{array}{l}-0.584 \\
-0.483\end{array}$ & $\begin{array}{l}-0.340 \\
-0.241\end{array}$ & $\begin{array}{l}-0.215 \\
-0.126\end{array}$ & $\begin{array}{l}-0.138 \\
-0.064\end{array}$ & $\begin{array}{l}-0.087 \\
-0.030\end{array}$ & $\begin{array}{l}-0.052 \\
-0.012\end{array}$ & $\begin{array}{l}-0.028 \\
-0.003\end{array}$ & $\begin{array}{l}-0.012 \\
-0.001\end{array}$ & $\begin{array}{r}-0.003 \\
0.000\end{array}$ \\
\hline Sum of lod-scores & $-1 \cdot 067$ & -0.581 & $-0 \cdot 341$ & -0.202 & -0.117 & -0.064 & -0.031 & -0.013 & -0.003 \\
\hline $\begin{array}{l}\text { Other studies } \\
\text { Blyth et al (1965) } 2 \text { families } \\
\text { Emery et al (1969) } 3 \text { families }\end{array}$ & $\begin{array}{l}-1.281 \\
-4.009\end{array}$ & $\begin{array}{l}-0.557 \\
-2.599\end{array}$ & $\begin{array}{l}-0.213 \\
-1.818\end{array}$ & $\begin{array}{l}-0.030 \\
-1.293\end{array}$ & $\begin{array}{r}0.065 \\
-0.915\end{array}$ & $\begin{array}{r}0.102 \\
-0.631\end{array}$ & $\begin{array}{r}0.102 \\
-0.409\end{array}$ & $\begin{array}{r}0.079 \\
-0.237\end{array}$ & $\begin{array}{r}0.041 \\
-0.104\end{array}$ \\
\hline Sum of lod-scores & $-5 \cdot 290$ & $-3 \cdot 156$ & $-2 \cdot 031$ & $-1 \cdot 323$ & -0.850 & -0.529 & -0.307 & $-0 \cdot 158$ & -0.063 \\
\hline Total sum of lod-scores & $-6 \cdot 357$ & $-3 \cdot 737$ & $-2 \cdot 372$ & -1.525 & -0.967 & -0.593 & -0.338 & $-0 \cdot 171$ & -0.066 \\
\hline Antilog = relative likelihood & 0 & 0 & 0.004 & 0.029 & $0 \cdot 108$ & $0 \cdot 255$ & 0.459 & 0.675 & 0.859 \\
\hline
\end{tabular}

by Emery (1966) suggests strongly that the DMD locus and the G6PD:deutan cluster are far apart on the $\mathrm{X}$ chromosome. On the other hand the possibility of a detectable linkage between the BMD and the deutan colour blindness loci, as suggested by Emery et al (1969) is strengthened by our data from families $\mathrm{G}$ and $\mathrm{H}$, since the joint analysis of their family and ours gives an estimate of 0.27 for $\theta$. The different estimates obtained for the DMD and BMD loci support the idea that the genes for the two X-linked types of muscular dystrophy are at different loci. It is wise, however, to consider this conclusion with caution, because very few families have been reported. More families with the Xlinked forms of muscular dystrophy should be studied, specially those where the maternal grandfather is also available, since Fraser and Mayo (1968) have shown for the Xg and G6PD loci, that linkage analysis in families with three or more generations, where recombinants and non-recombinants can be counted directly, may lead to estimates rather divergent from those obtained from two-generation families analysed by the lod-score method.

This work was supported by the Fundação de Amparo à Pesquisa do Estado de São Paulo (FAPESP), Organização dos Estados Americanos (Programa Multinacional de Genética), Conselho Nacional de Pesquisas (CNPq) and the World Health Organization (WHO).

The collaboration of the following physicians is gratefully acknowledged: $\mathrm{Dr}$ J. A. Levy and all the medical staff of the Hospital das Clínicas de São Paulo; Dr José Laredo Filho and all the medical staff of the Associação de Assistência à Criança Defeituosa.

We would also like to thank Mrs Maria do Carmo Rabello Lockley for typing the manuscript and Mrs Priscilla Otto and Dr P. A. Otto for drawing the figures. 


\section{REFERENCES}

Adam, A. (1961). Linkage between deficiency of glucose-6-phosphate dehydrogenase and colour-blindness. Nature, 189, 686.

Becker, P. E. (1955). Zur Genetik der Myopathien. Deutsche Zeitschrift für Nervenheilkunde, 173, 482.

Becker, P. E. and Kiener, F. (1955). Eine neue X-chromosomale Muskeldystrophie. Archiv für Psychiatrie und Nervenkrankheiten, 193, 427.

Blyth, H., Carter, C. O., Dubowitz, V., Emery, A. E. H., Gavin, J., Johnston, H. A., McKusick, V. A., Race, R. R., Sanger, R., and Tippett, P. (1965). Duchenne's muscular dystrophy and the Xg blood groups: a search for linkage. Fournal of Medical Genetics, 2, 157-160.

Clark, J. I., Puite, R. H., Marczynski, R., and Mann, J. D. (1963). Evidence for the absence of detectable linkage between the genes for Duchenne muscular dystrophy and the $\mathrm{Xg}$ blood group. American fournal of Human Genetics, 15, 292-297.

Emery, A. E. H. (1966). Genetic linkage between the loci for colour blindness and Duchenne type muscular dystrophy. fournal of Medical Genetics, 3, 92-95.

Emery, A. E. H., Smith, C. A. B., and Sanger, R. (1969). The linkage relations of the loci for benign (Becker type) X-borne muscular dystrophy, colour blindness and the $\mathrm{Xg}$ blood groups. Annals of Human Genetics, 32, 261-269.

Filippi, G. and Macciotta, A. (1967). Xg blood-groups in muscular dystrophy. Lancet, 2, 565.

Fraser, G. R., Defaranas, B., Kattamis, C. A., Race, R. R., Sanger, R., and Stamatoyannopoulos, G. (1964). Glucose-6-phosphate dehydrogenase, colour vision and $\mathrm{Xg}$ blood groups in Greece: linkage and population data. Annals of Human Genetics, 27, 395403.

Fraser, G. R. and Mayo, O. (1968). A comparison of the twogeneration and three-generation methods of estimating linkage values in the $\mathrm{X}$ chromosome in man with special reference to the loci determining the Xg blood group and Glucose-6-P Dehydrogenase deficiency. American fournal of Human Genetics, 20, 534548.

Maynard-Smith, S., Penrose, L. S., and Smith, C. A. B. (1961). Mathematical Tables for Research Workers in Human Genetics. J. and A. Churchill, London.

Morton, N. E. (1955). Sequential tests for the detection of linkage. American fournal of Human Genetics, 7, 277-318.

Opitz, J. M., Stiles, F. C., Wise, D., Race, R. R., Sanger, R., Gemmingen 'G. R. von, Kierland, R. R., Cross, E. G., and Groot, W. P. de. (1965). The genetics of angiokeratoma corporis diffusum (Fabry's disease) and its linkage relations with the $\mathrm{Xg}$ locus. American fournal of Human Genetics, 17, 325-342.

Philip, U., Walton, J. N., and Smith, C. A. B. (1956). Colour blindness and the Duchenne-type muscular dystrophy. Annals of Human Genetics, 21, 155-158.

Porter, I. H., Schulze, J., and McKusick, V. A. (1962). Genetical linkage between the loci for glucose-6-phosphate dehydrogenase and colour-blindness in American negroes. Annals of Human Genetics, 26, 107-122.

Rotthauwe, H. W. and Kowalewski, S. (1966). Gutartige recessiv $\mathrm{X}$-chromosomal vererbte Muskeldystrophie: Untersuchungen bei Merkmalsträgern. Humangenetik, 3, 17-29.

Saldanha, P. H., Nobrega, F. G., and Maia, J. C. C. (1969). Distribution and heredity of erythrocyte G6PD activity and electrophoretic variants among different racial groups at São Paulo Brazil. Fournal of Medical Genetics, 6, 48-54.

Sigma, (1967). Creatine phosphokinase (CKP) on serum or other fluids. SIGMA Technical Bulletin No. 520/80-F, 5-9.

Siniscalco, M. (1963). Linkage data for G6PD deficiency in Sardinian villages. In The Genetics of Migrant and Isolate Populations, ed. by E. Goldschmidt, pp. 106-116. Williams and Wilkins, Baltimore.

Walton, J. N. (1969). Carrier detection in X-linked muscular dystrophy. Fournal de Génétique Humaine, 17, 497-510. 